\title{
Kosovo - EU Trade Relations: A Dynamic Panel Poisson Approach
}

Petrit Gashi*, Mehtap Hisarciklilar ${ }^{\dagger}$ and Geoffrey Pugh*

Running title: Kosovo - EU Trade Relations

\begin{abstract}
To inform policy making following trade liberalisation between Kosovo and the EU within the framework of the Stabilisation and Association Agreement, we specify a gravity model to investigate Kosovo's trade in goods with $28 \mathrm{EU}$ countries, over the period 2005-2013. We reconcile competing methodological requirements by using a dynamic Poisson approach to estimation. Together, persistent trade patterns and an unfavourable combination of demand and supply elasticities suggest that trade liberalisation in isolation is not sufficient to promote exports but may need to be incorporated within a wider policy and institutional framework. In addition, our findings suggest that trade costs should be a particular focus for policy: distance has a big negative influence on Kosovo's exports to EU countries; while diaspora communities promote Kosovo's exports to EU markets, most likely because they offset trade costs.
\end{abstract}

Key words: Kosovo-EU trade; Gravity model; Dynamic Poisson estimation; Diaspora

JEL classification: F14; P33

\footnotetext{
* Petrit Gashi

Faculty of Economics, University of Prishtina, e-mail: petrit.gashi@uni-pr.edu

${ }^{\dagger}$ Corresponding author: Mehtap Hisarciklilar Staffordshire University Business School, Leek Road, Stoke-on-Trent, ST4 2DF, UK e-mail: M.Hisarciklilar@staffs.ac.uk

$\$$ Geoff Pugh Staffordshire University Business School, e-mail: g.t.pugh@staffs.ac.uk
}

Acknowledgement: The authors would like to acknowledge generous financial support by the Kosovo Foundation for Open Society. 


\section{INTRODUCTION}

In spite of improved performance in recent years, the 2013 EU Progress Report concluded that Kosovo's economic growth remains weak and fragile. ${ }^{1}$ Together with the high level of unemployment, the negative trade balance remains a challenging issue in Kosovo. In summary, the share of goods exports in GDP was only 3 per cent in 2008 rising to 4 per cent in 2013. Goods exports cover only around 12 per cent of goods imports. Another discouraging sign regarding the trade in goods is the low degree of export diversification and the predominance of low value added goods, such as base metals and minerals together constituting about two-thirds of total exports in the last few years (for further detail, see Gashi and Pugh, 2015).

The Government of Kosovo has undertaken a number of policy and institutional steps to strengthen the export sector. In particular, trade with its two major trading blocks, namely the neighbouring Western Balkan countries within the Central European Free Trade Agreement (CEFTA) and the EU, has been almost fully liberalized. Negotiations on the Stabilisation and Association Agreement (SAA) between the EU and Kosovo were formally launched in October 2013, while the agreement entered into force in April 2016. The trade liberalisation component of the SAA will further strengthen EU-Kosovo trade relations. ${ }^{2}$ Currently, around half of Kosovo's trade is conducted with the EU. ${ }^{3}$ All $28 \mathrm{EU}$ member states have exported to Kosovo at one time or another, whereas Kosovo's exports to a number of EU countries are virtually zero (for instance, Malta, Luxemburg, and Estonia). The major trading partners are similar for both exports and imports: Germany, Italy, Greece, Slovenia, and Belgium.

Reflecting the focus of trade liberalisation on goods and corresponding data availability, this article analyses for the first time the determinants of Kosovo's import and export trade in goods with the EU and so contributes to the knowledge base of policy initiatives

\footnotetext{
${ }^{1}$ http://ec.europa.eu/enlargement/pdf/key_documents/2013/package/ks_rapport_2013.pdf (accessed on: January 30, 2014).

${ }^{2}$ The current trade regime of Kosovo is fairly simple. It applies only two import tariff rates, namely zero and 10 per cent rates. Non-tariff instruments are virtually non-existent.

${ }^{3}$ Less than 20 per cent of trade is conducted with countries outside the EU and CEFTA, notably with Turkey and China. In October 2013 Kosovo signed a FTA with Turkey. The entry into force of the Agreement awaits ratification by the respective Parliaments. See Central Bank of Kosovo (2014) Buletini Mujor Statistikor (April edition) in http://www.bqk-kos.org/repository/docs/2014/BMS\%20nr\%20152\%20shqip.pdf (accessed on: October $2^{\text {nd }} 2016$ ).
} 
to respond to the threats and opportunities created by trade liberalisation. To this end, we highlight three competing methodological requirements in specifying a gravity model: theory-consistent modeling of multilateral trade resistance and promoting factors; Poisson estimation to take account of heteroskedasticity and of zero entries in the trade matrix; and dynamic modelling to take account of historical influences. The first of these requirements is now universally acknowledged in gravity modelling, and the second is becoming so; yet the third is far from common practice. A contribution of this paper is to argue for the third and to address all three requirements. Accordingly, we analyse a 9year panel (2005-2013), including both aggregate and sectoral trade data, by estimating to our knowledge, for the first time in the trade literature - dynamic Poisson panel models.

Our findings are consistent with a stream of literature suggesting that the benefits of free trade are conditional and that export performance in general depends on many domestic supply-side factors (Newberry and Stiglitz, 1984; OECD/WTO/World Bank, 2014). Moreover, just as Redding and Venables (2004, p.104 and Table 3A.1) argue in relation to Eastern European countries, our findings suggest that Kosovo will have to address its supply-side weaknesses if the potential benefits of free trade are to be realised. Other findings with policy implications are the importance of Kosovo's diaspora community in promoting exports, and that distance - a proxy for trade costs - deters trade, particularly exports.

\section{EMPIRICAL ANALYSIS}

\subsection{The Gravity Model and Econometric Estimation}

Following Anderson (1979) and subsequent work by Anderson and van Wincoop (2003), Baldwin and Taglioni (2007), and Anderson (2010), a theoretically consistent gravity model of trade flows has the following form (Baldwin and Taglioni, 2007, p.786; see also WTO, 2012): ${ }^{4}$

$$
\text { bilateral trade flows }=G \frac{Y_{o} Y_{d}}{\text { distance } e_{\text {od }}^{\sigma-1}}
$$

The conventional or "naïve" gravity model relates international trade flows positively to the product of the GDPs of the trade partners ( $Y_{o}$ in the "origin" country and $Y_{d}$ in the "destination" country) and inversely to the distance between their capital cities (to proxy trade costs). The theoretically consistent gravity model differs in two respects: by taking

\footnotetext{
${ }^{4}$ The model applies to both exports and imports. For convenience we refer to exports.
} 
into account the elasticity of substitution between traded products $(\sigma>1)$; and - above all - in the definition of $G$. Whereas in the conventional model $G$ is a constant, Baldwin and Taglioni (2007, p.787) characterise $G$ as the "gravitational un-constant", because it "is a variable that includes all the bilateral trade costs between nations $o$ and $d$ so it will be different for every pair of trade partners, and it will vary over time'. $G$ is 'what Anderson and Van-Wincoop call the multilateral trade resistance' (Baldwin and Taglioni, 2007, p.790) and captures influences on bilateral trade flows that are largely unobservable. Moreover, if ignored in estimation, $G$ will give rise to omitted variables bias. To anticipate, $G$ can be controlled for by exploiting the potential of panel data to support a rich variety of fixed effects. Yet, we argue that empirical specification should take account of two additional considerations: firstly, the case for Poisson estimation to address sources of bias associated with the traditional approach of estimating Equation 1 in log-linear form; and, secondly, the case for estimating a dynamic model. In the following discussion, we explain how these considerations entail competing priorities and the corresponding trade-offs involved in our model specification and choice of estimator.

The log-linear form of the gravity equation requires logarithmic transformation of the continuous variables, such as trade, GDPs and distance. Yet bilateral trade datasets, including ours, contain many zero values, which cannot be subject to logarithmic transformation. For Kosovo this would be a real handicap, as zero trade flows dominate the export data. Moreover, from the empirical point of view, the greater the disaggregation of the data the greater the number of zero values in the matrix. Hence, omission of zeros would greatly affect our estimations at the sectoral level. We follow Santos Silva and Tenreyro (2006 and 2011) who show that the Poisson model performs strongly even in datasets with a large proportion of zero values. In addition, for estimating gravity models based on the non-linear theoretical form (Equation 1), under the assumption of a multiplicative error term, Poisson estimation accounts for the presence of heteroskedasticity (see Santos Silva and Tenreyro, 2011; and Shepherd, 2013, pp.51-52). For these reasons, and particularly given the huge increase in sample size (especially for sector analysis), Poisson estimation is our preferred approach. Inclusion of zeros results in a drastic change in our sample size, especially for aggregate exports and sectoral exports and imports: for aggregate exports, zero entries are 15.1 per cent of the total; while for the sectoral export and import databases the share of zeros is, respectively, 89.1 and 50.0 per cent. ${ }^{5}$

\footnotetext{
${ }^{5}$ To assess whether there is underreporting of trade data between Kosovo and the EU, and with that a likely increase of zeros in the databases, we investigated "mirrored" trade data; i.e. we compared the trade data
} 
We include in the model variables to account for historical patterns of trade: the first lagged values of the dependent variable; and the initial condition variable (i.e. the level of exports or imports in 2005). Both theory and empirical evidence suggest that history plays a significant role in shaping international trade flows (De Benedictis and Taglioni, 2011, p.85). In their seminal work, Eichengreen and Irwin (1998, p. 55) strongly support this view; according to them, countries with a history of trading with one another continue to do so either for political, policy, or other related reasons. The authors argue that changes in trade flows can produce effects with significant persistence. Accordingly, the authors argue that the omission of historical factors is likely to bias estimated trade effects. ${ }^{6}$

To model the dynamics of bilateral trade flows we specify a dynamic panel model, i.e. a model that includes the lagged dependent variable - in this case, lagged trade - among the explanatory variables. The economic argument presented by Eichengreen and Irwin (1998) is consistent with the econometric importance of modelling dynamics as outlined by Greene (2008, p.469; emphasis added):

Without the lagged variable, the "independent variables" represent the full set of information that produce observed outcome $y_{i t}$. With the lagged variable, we now have in the equation the entire history of the right-hand-side variables, so that any measured influence is conditional on this history; in this case, any impact of (the independent variables) $\boldsymbol{x}_{i t}$ represents the effect of new information.

reported by Kosovo sources used in this study with the corresponding trade data reported by Kosovo's trade partners. However, mirror data does not resolve the issue of zeros. Indeed, the mirror data from Kosovo's trade partners contain even higher numbers of zeros than those reported by Kosovo's statistics. It seems that the differences observed, especially after 2009, in Kosovo exports and import data are typical, and within the "acceptable range", for international trade data (see Carrère, 2014; Guo, 2009 in the case of China; and, Simola, 2012, for Russia). For readers interested in this topic, a detailed comparison has been made available in an on-line Appendix.

${ }^{6}$ The firm-level evidence, theoretical and empirical, likewise suggests the influence of history on current trade patterns. For instance, learning theory - rooted in the behavioural theory of the firm - argues that development of knowledge and its renewal with regard to domestic and foreign activities may have an impact on perceptions about opportunities offered by further internationalisation (see Clercq et al., 2005). In addition, Melitz (2003) argues that the firm's export entry and exit decisions are determined by the interplay of two factors: firm-level variation in productivity; and sunk costs. Empirically, export experience has been used to explain patterns of firms' entry and exit strategies in the presence of sunk costs (Roberts and Tybout, 1997; Bernard and Wagner, 1998; and Bernard and Jensen, 2004). 
The econometric reasons for including the initial condition in a dynamic Poisson model are explained in Wooldridge (2005). Controlling for country-specific effects is problematic in the context of a dynamic specification in which the unobserved effect is part of the composed error term and thus - by construction - correlated with the lagged dependent variable. However, following Wooldridge (2005), this problem is addressed by estimating a dynamic Poisson model conditional on both the initial value of trade and 'the time average of the time-varying exogenous variables' (Cameron and Trivedi, 2013, p.376).

Taking into account both the economic argument for introducing the history of trade flows and the econometric means of doing so, the Wooldridge (2005) dynamic Poisson panel model is well suited to estimate a theory-consistent gravity model. However, our model specification still has to address two other issues highlighted in the recent literature: controlling for multilateral trade resistance factors ( $G$ in Equation 1); and other potential sources of endogeneity.

Baldwin and Taglioni (2007, p.786) show that the multilateral trade resistance factors can be modelled by dummy variables that capture all the bilateral trade costs between pairs of origin and destination countries ('so it is different for every pair of trade partners, and it will vary over time'). Further, they analyse the two most common ways to address this issue, namely (p.799): specifying the gravity model either with country dummies; or with country-pair dummies, which in a panel model 'is just the classic fixed effects estimator'. In comparing the relative merits of these two approaches, Baldwin and Taglioni (2007, p.799) state that while both remove cross-sectional sources of bias, neither removes potential time-series correlations between the omitted trade influences and variables included in the model, hence some bias may remain. However, the authors conclude that the pair-dummy is 'superior to national dummies in panel data' (p.802). Other approaches to controlling for multilateral trade resistance factors require even more dummy variables. By extension, in the analysis of panel sector data, country-industry specific time-varying effects should be applied. Yet Baldwin and Taglioni (2007, p.811) explain why a 'timevarying pair dummy approach will rarely be useful', while Shepherd (2013, p.38) notes that 'models including a large number of sectors quickly become unmanageable due to the number of parameters involved ... and may even prove impossible to estimate with some numerical methods such as Poisson' (on these computational difficulties, see also De Benedictis and Taglioni, 2011, p.74; and Head and Mayer, 2013, pp.21, 23, 26, 48 and 50). In this study, this practical limitation applied not only to our sector models but also to our aggregate models; dynamic Poisson models with full sets of time-varying importer and exporter dummies could not be estimated at all. 
Accordingly, in this study, our compromise is to estimate dynamic Poisson models that control for country-pair effects at aggregate level and country-pair by sector effects at sectoral level. In addition, we estimate trade flows conditional on year dummies, which control for time-varying multilateral trade resistance effects to the extent that these are similar across the country pairs. This combination of effects is "probably the most common' in the literature (Baldwin and Taglioni, 2007, p.805). Specification with year dummies also serves the statistical function of minimising the potential for cross-group error correlation arising from common shocks in particular periods (one such common shock would be the temporary termination of Autonomous Trade Measures by the EU in $\left.2011^{7}\right)$.

The second issue is that policy variables may be potentially endogenous. In our model, the only policy variable included is the common currency. In general, one could argue that the adoption of a common currency is conditional on established trade patterns, and is thus potentially endogenous. However, in the case of Kosovo this presumption does not stand. The adoption of the euro was an outcome of the peace process following the 1999 war. At that time, Kosovo had no institutional infrastructure in place to conduct a monetary policy, including managing its own currency. Hence, it was decided to introduce the euro as legal tender. Similarly, there is not a strong case for treating our remittances variable as endogenous with respect to trade flows. By the time of our sample period, Kosovo's diaspora was largely conflict driven so there is no presumption that the location of diaspora communities within the EU is trade driven (on the motives for emigration, see Riinvest, 2007).

The empirical form of our dynamic Poisson model is set out in Equation 2 and is estimated with random effects by xtpoisson in Stata 13. Starting with the selection of the dependent variable, the literature states that a number of alternatives can be used, such as total trade, export flows, import flows, or average bilateral trade flows. De Benedictis and Taglioni (2011), Shepherd (2013), and others, argue that unidirectional import and export data should be used, as other choices are likely to produce misleading results. Accordingly, each line in our database represents a single flow, either exports from Kosovo to the EU countries, or imports from the EU countries to Kosovo (variables respectively denoted as $e x \_k s$ and $i m \_k s$; see Table 1 ).

\footnotetext{
${ }^{7}$ For more information see http://eeas.europa.eu/delegations/kosovo/press corner/focus/2011/120104 atm_en.htm (accessed on August 2, 2014).
} 


$$
\begin{aligned}
& e x_{-} k s_{j, t}=\beta_{1} e x_{-} k s_{j, t-1}+\beta_{2} e x_{-} k s_{j, t=0}+\beta_{3} l l_{-} i m p_{-} g d p_{j, t}+\beta_{4} l n_{-} \exp _{-} g d p_{t}+ \\
& \beta_{5} l n_{-} d i s_{-} k m_{j}+\beta_{6} c o m c_{j, t}+\beta_{7} \ln _{-} r e m_{j, t}+\beta_{8}{\overline{l m p} \_g d p_{j}}+\beta_{9} \overline{r e m}_{j}+\text { constant }+ \\
& \alpha_{j}+\varepsilon_{j, t}
\end{aligned}
$$

The same model is estimated for aggregate imports with the appropriate substitutions (see Table 1 for an explanation of variables and descriptive statistics). In both cases, values for Kosovo do not vary between country pairs and so are not indexed; EU countries are indexed by $j$; and years by $t$. The subscript $t=0$ denotes the initial period. The sectoral models have the same form but with an additional subscript to denote sector variation. Transformation of a variable into natural logarithms is denoted by $\ln$. Finally, the model includes the constant and $\varepsilon$, the observation level error term, and random effects $\alpha_{j}$ to control for otherwise unobserved trade effects between Kosovo and each country $j$. The within-group means of the time-varying continuous exogenous variables are included in the specification in accord with Wooldridge (2005) and are denoted by a horizontal bar above the respective variables. Group means are included for importer's GDP and remittances; Kosovo's GDP is invariant across countries (aggregate data) and countrysectors (sectoral data), hence the group mean of this variable cannot be additionally controlled for.

The theory suggests that both GDP variables should relate positively to the trade flows between countries. In the case of the importer's GDP ( $i m p \_g d p$ ), theory suggests a positive relationship between increasing income and bilateral trade flows. Seen from the perspective of the country of origin, increased income (exp_gdp) is associated with enhanced supply capacity and, hence a positive export effect. The distance factor is a proxy for bilateral trade costs $\left(d i s \_k m\right.$ ), including: transportation costs (freight and time costs); information costs; contract enforcement costs; legal and regulatory costs; and local distribution costs. The expected relationship between distance and bilateral trade is negative.

The gravity equation is typically augmented to incorporate numerous trade and other policy variables. Most of these are not relevant to this study, as Kosovo does not share the corresponding geographical or historical features with the EU - e.g. common border and common language. However, following the war in 1999, in the context of the peace process, Kosovo decided to introduce the euro as legal tender. Accordingly, we introduce a dummy variable for the EU countries that have adopted the euro (comc).

Many studies associate migration/diaspora and remittances with the alleviation of poverty and economic development in the country of origin. Among a number of channels as to 
how this is achieved, the literature provides evidence of a positive relationship between trade and migration. The literature has identified two channels through which the diaspora fosters trade between the country of residence and the country of birth/origin: firstly, through reduction of transaction costs; and, second, by demanding domestically produced goods (Gould, 1994; Parsons, 2012; Egger et al., 2012). The first channel is particularly important, and warrants further attention. Egger et al. (2012) explain that the reduction of transaction costs comes through the reduction of uncertainty (associated with incomplete information) and of opportunism (associated with asymmetric information). Diaspora communities face no language barrier, as they are often bilingual. They are in tune with the legislation in both countries, and may have the necessary knowledge of the available products in both countries. Further, the diaspora community is ideally positioned to promote contacts and networking between buyers and sellers, thereby overcoming informational asymmetries and lowering the transaction costs of trade. On the second channel, Egger et al. (2012) argue that a diaspora community, through demonstration effects, would increase the demand for immigrant-preferred goods also among natives. Because there is no direct data on the Kosovan diaspora and its economic role in EU countries, we make use of recently available remittances data to model the potential influence of the diaspora. Because only substantial flows are recorded, most are set to zero. Accordingly, each of our models is specified in two variants: with yearly remittances from the EU countries (rem); and with a dummy variable for those EU countries with a diaspora community sufficiently substantial for remittance data to be recorded $\left(r e m \_d\right)$.

Santos Silva and Tenreyro (2006, p.654) explain that the dependent variable in the Poisson model is specified in 'levels' rather than in logarithms, hence as Shepherd (2013, p.52) notes, the coefficients of independent variables entered in logarithms are interpreted as simple or constant elasticities, while 'the coefficients of independent variables entered in levels are interpreted as semi-elasticities, as under OLS'. In addition, Santos Silva and Tenreyro (2006, p.654) make clear that dummy variables in the Poisson model are to be interpreted in the same way as in a model with a dependent variable specified in logarithms estimated by OLS. ${ }^{8}$

\footnotetext{
${ }^{8}$ We also follow Santos Silva and Tenreyro (2011, p. 210) in rescaling continuous variables in the model by dividing through by 10 million, as the dynamic Poisson estimator in Stata (>xtpoisson<) is known to have convergence issues when the database contains very large values.
} 


\subsection{The Data}

The study utilizes the database of External Trade Statistics, a 9-year panel (longitudinal) provided by the Kosovo Agency of Statistics. The annual data cover the period from 2005 until 2013. At the time of writing, the available data included only trade in goods with the EU. We do not use data prior to 2005 , because it is known to be unreliable. In addition to aggregate data, the database provides disaggregated data at the 2-digit HS level. The study utilizes World Bank World Development Indicators for the nominal GDP of countries, ${ }^{9}$ and "viamichelin.com" for the actual travel distance $(\mathrm{km})$ between capital cities. ${ }^{10}$ Remittance data are obtained from the Central Bank of Kosovo.

\footnotetext{
${ }^{9}$ It is now widely accepted that the nominal variables are to be used in the gravity equation (Shepherd, 2013, p.15).

${ }^{10}$ See www.viamichelin.com (accessed on: November - December 2014). Our preference for actual travel distances rather than the great circle distances, which are commonly (but not uniformly) used in the gravity literature, is informed by Disdier and Head (2008) (see, in particular, pp.41 and 44).
} 
Table 1: Variable description and summary statistics for aggregate data

\begin{tabular}{|c|c|c|c|c|c|c|c|}
\hline \multirow{2}{*}{ Variables } & \multirow{2}{*}{ Description } & \multirow{2}{*}{ Mean } & \multirow{2}{*}{ St. dv. } & \multirow{2}{*}{ Min } & \multirow{2}{*}{ Max } & \multicolumn{2}{|c|}{ Fractions } \\
\hline & & & & & & 1 & 0 \\
\hline \multicolumn{8}{|l|}{ Dependent variables } \\
\hline $\begin{array}{l}\text { Kosovo's exports } \\
\left(e x \_k s\right)\end{array}$ & The monetary value of exports from Kosovo to the EU, $€ 10 \mathrm{mil}$. & 0.3 & 1.1 & 0.0 & 8.4 & - & - \\
\hline $\begin{array}{l}\text { Kosovo's imports } \\
\left(i m \_k s\right)\end{array}$ & The monetary value of imports from the EU to Kosovo, €10mil. & 2.8 & 5.0 & 0.0 & 30.0 & - & - \\
\hline \multicolumn{8}{|l|}{ Independent variables } \\
\hline $\begin{array}{l}\text { Kosovo's GDP } \\
\left(i m p \_g d p / \exp \_g d p\right)\end{array}$ & Nominal GDP of the importing/exporting country, $€ 10 \mathrm{mil}$. & 412.3 & 79.4 & 300.9 & 532.5 & - & - \\
\hline 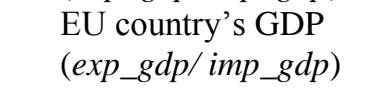 & Nominal GDP of the exporting/importing country, $€ 10 \mathrm{mil}$. & $45,510.2$ & $68,868.5$ & 480.8 & $280,905.0$ & - & - \\
\hline Distance $($ dis_km) & Actual travel distance in kilometres between capital cities & $1,706.7$ & 829.1 & 286.0 & $3,504.0$ & - & - \\
\hline $\begin{array}{l}\text { Common currency } \\
(\text { comc })\end{array}$ & $\begin{array}{l}\text { Dummy for countries which have introduced } € \text { as a national } \\
\text { currency }\end{array}$ & - & - & - & - & 77.0 & 23.0 \\
\hline $\begin{array}{l}\text { Diaspora dummy } \\
(\text { rem_d })\end{array}$ & $\begin{array}{l}\text { Dummy for the eleven EU countries with the largest proportions } \\
\text { of the Kosovan diaspora (Austria, Belgium, Denmark, Finland, } \\
\text { France, Germany, Italy, Netherlands, Slovenia, Sweden, UK). } \\
\text { These are the countries for which remittance data is sufficiently } \\
\text { large to be recorded. Those EU countries from which no } \\
\text { significant remittance flows are recorded have no substantial } \\
\text { diaspora communities. }\end{array}$ & - & - & - & - & 39.3 & 60.7 \\
\hline $\begin{array}{l}\text { Diaspora remittances } \\
(\text { rem) }\end{array}$ & $\begin{array}{l}\text { The value of remittances from Kosovo's main diaspora } \\
\text { communities (listed above), } € 10 \text { mil. For logarithmic } \\
\text { transformation, zero values are set to one euro. This data is } \\
\text { available only from } 2008 \text { onwards. }\end{array}$ & 3.6 & 5.7 & 0.2 & 23.0 & - & - \\
\hline
\end{tabular}




\section{RESULTS AND DISCUSSION}

Tables 2 and 3 present the estimated effects of our variables of interest on the respective export and import flows. ${ }^{11}$ For both exports and imports, we report six models: aggregate and sectoral flows, each with the Diaspora dummy and then with the values of remittances. The latter variants reflect a trade-off between the greater number of observations available when estimating with the dummy and the ability to make causal inferences from the continuous variable. ${ }^{12}$ Wooldridge (2005) explains that while continuous exogenous variables yield causal inferences, dummy variables may fulfil only a control function. Accordingly, our preferred models are those estimated on sectoral data and with the value of remittances, as these yield precise estimates with valid causal interpretation. In addition, our two sector models are each estimated in two variants; first with default standard errors; and then with cluster-robust standard errors (to take account of unmodelled patterns of dependence among the errors at country-pair-sector level). ${ }^{13,14}$ Each model includes year dummies as well as group averages for each time-varying exogenous variable, which are required as additional controls in a dynamic Poisson specification (Wooldridge, 2005).

\subsection{The Role of History}

In each export and import model, we find positive coefficients on lagged trade and the initial trade condition. Yet, in the sectoral estimates, the contrast between the levels of statistical significance for these effects using default and cluster-robust standard errors respectively is severely out of proportion to the contrast for our other estimates. (In Tables 2 and 3 compare Columns 3 and 5 with 4 and 6.) This contrast raises an issue for the estimation of clusterrobust standard errors that has not - to our knowledge - been noted in the literature and is thus considered in more detail at the end of this Section. Meanwhile, we interpret the sign and size of the estimated effects of lagged and initial trade.

The findings confirm our preference for the dynamic modelling of Kosovo's trade as well as the specification of our model with initial conditions for both econometric and economic reasons.

\footnotetext{
${ }^{11}$ To facilitate replication, the variable names on the dynamic terms are given as they appear in the dataset.

${ }^{12}$ Remittance data is available from 2008 onwards; see Table 1. The Diaspora dummy enables full use of the other data series, which all begin in 2005.

${ }^{13}$ Clustering effects in the errors have been highlighted as likely within country pairs or country sector pairs in gravity models (Shepherd, 2013, p.29).

${ }^{14}$ The aggregate models have insufficient clusters for bootstrapping cluster-robust standard errors.
} 
Table 2. Determinants of bilateral exports $\left(e x \_k s\right)$ : model estimates ${ }^{i}$

\begin{tabular}{|c|c|c|c|c|c|c|}
\hline & $\begin{array}{r}\text { Aggregate data } \\
\text { Diaspora } \\
\text { dummy }\end{array}$ & $\begin{array}{r}\text { Aggregate data } \\
\text { Remittances }\end{array}$ & $\begin{array}{r}\text { Sectoral data } \\
\text { Diaspora } \\
\text { dummy } \\
\text { OIM SE }\end{array}$ & $\begin{array}{r}\text { Sectoral data } \\
\text { Diaspora } \\
\text { dummy } \\
\text { Clustered SE } \text { E }^{\mathrm{iii}}\end{array}$ & $\begin{array}{r}\text { Sectoral data } \\
\text { Remittances } \\
\text { OIM SE }\end{array}$ & $\begin{array}{l}\text { Sectoral data } \\
\text { Remittances } \\
\text { Clustered SE }\end{array}$ \\
\hline Lagged exports & $0.234 * * *$ & 0.291 *** & $0.799 * * *$ & 0.799 & $0.813 * * *$ & 0.813 \\
\hline$\left(L . e x \_k s\right)$ & $(0.065)$ & $(0.078)$ & $(0.095)$ & $(2.035)$ & $(0.100)$ & $(2.373)$ \\
\hline Initial exports & $2.364 * *$ & 0.946 & $13.626 * * *$ & $13.626^{*}$ & $11.497 * * *$ & 11.497 \\
\hline$\left(T 0 \_e x \_k s\right)$ & $(1.033)$ & $(1.141)$ & $(2.374)$ & $(7.043)$ & $(2.194)$ & $(7.485)$ \\
\hline Log of importer's GDP (EU) & 0.168 & 0.440 & 0.097 & 0.097 & 0.313 & 0.313 \\
\hline$\left(l n \_i m p \_g d p\right)$ & $(0.240)$ & $(0.298)$ & $(0.249)$ & $(0.261)$ & $(0.289)$ & $(0.233)$ \\
\hline Log of exporter's GDP (Kosovo) & 4.427 & 0.742 & 5.186 & 5.186 & 2.329 & 2.329 \\
\hline$\left(l n \_e x p \_g d p\right)$ & $(6.480)$ & $(10.480)$ & $(6.531)$ & $(3.637)$ & $(10.557)$ & $(4.912)$ \\
\hline Log of distance & $-1.308 * * *$ & $-1.023 * *$ & $-1.754 * * *$ & $-1.754 * * *$ & $-1.039 * * *$ & $-1.039 * *$ \\
\hline$($ ln_dis_km) & $(0.418)$ & $(0.406)$ & $(0.391)$ & $(0.568)$ & $(0.376)$ & $(0.408)$ \\
\hline Common currency dummy & -0.158 & -0.276 & -0.001 & -0.001 & -0.349 & -0.349 \\
\hline$(\mathrm{comc})$ & $(0.502)$ & $(0.564)$ & $(0.497)$ & $(0.484)$ & $(0.574)$ & $(0.449)$ \\
\hline $\begin{array}{l}\text { Diaspora dummy } \\
(\text { rem_d })\end{array}$ & $\begin{array}{r}1.677 * * * \\
(0.460)\end{array}$ & & $\begin{array}{r}2.190 * * * \\
(0.522)\end{array}$ & $\begin{array}{r}2.190 * * * \\
(0.396)\end{array}$ & & \\
\hline $\begin{array}{l}\text { Log Diaspora remittances } \\
(\text { ln_rem })\end{array}$ & & $\begin{array}{r}1.087 * * \\
(0.452)\end{array}$ & & & $\begin{array}{r}1.537 * * * \\
(0.473)\end{array}$ & $\begin{aligned} 1.537 * * \\
(0.626)\end{aligned}$ \\
\hline Constant & $\begin{array}{l}-20.933 \\
(37.579)\end{array}$ & $\begin{array}{r}-3.083 \\
(60.700)\end{array}$ & $\begin{array}{r}-26.542 \\
(37.828)\end{array}$ & $\begin{array}{r}-26.542 \\
(22.120)\end{array}$ & $\begin{array}{r}-15.677 \\
(61.070)\end{array}$ & $\begin{array}{l}-15.677 \\
(29.101)\end{array}$ \\
\hline Year dummies & YES & YES & YES & YES & YES & YES \\
\hline $\begin{array}{l}\text { Group means of time-varying } \\
\text { continuous exogenous variables }\end{array}$ & YES & YES & YES & YES & YES & YES \\
\hline Number of observations & 224 & 202 & 21,728 & 21,728 & 19,594 & 19,594 \\
\hline
\end{tabular}

Levels of significance are indicated in the conventional manner: *** $p<0.01 ; * * p<0.05 ; * p<0.1$. Standard errors are reported in parentheses.

(i) Models estimated at aggregate and sectoral level, respectively, control for country-pair and country-pair by sector time invariant unobserved effects.

(ii) The Group means of importer's GDP and remittances; Kosovo's GDP is invariant across countries (aggregate data) and country-pair-sectors (sectoral

data), hence the group mean of this variable cannot additionally be controlled for.

(iii) Bootstrapped standard errors with 250 replications. 
Table 3. Determinants of bilateral imports $\left(i m \_k s\right)$ : model estimates ${ }^{i}$

\begin{tabular}{|c|c|c|c|c|c|c|}
\hline & $\begin{array}{l}\text { Aggregate data } \\
\text { Diaspora } \\
\text { dummy }\end{array}$ & $\begin{array}{l}\text { Aggregate data } \\
\text { Remittances }\end{array}$ & $\begin{array}{c}\text { Sectoral data } \\
\text { Diaspora } \\
\text { dummy } \\
\text { OIM SE }\end{array}$ & $\begin{array}{c}\text { Sectoral data } \\
\text { Diaspora } \\
\text { dummy } \\
\text { Clustered SE }\end{array}$ & $\begin{array}{c}\text { Sectoral data } \\
\text { Remittances } \\
\text { OIM SE }\end{array}$ & $\begin{array}{l}\text { Sectoral data } \\
\text { Remittances } \\
\text { Clustered SE }\end{array}$ \\
\hline Lagged imports & $0.025^{*}$ & $0.033^{*}$ & $0.163 * * *$ & 0.163 & $0.232 * * *$ & 0.232 \\
\hline (L.im_ks) & $(0.013)$ & $(0.017)$ & $(0.059)$ & $(0.264)$ & $(0.069)$ & $(0.257)$ \\
\hline Initial imports & $0.279 * * *$ & $0.493 * * *$ & $6.839 * * *$ & $6.839 * * *$ & $6.525 * * *$ & $6.525 * * *$ \\
\hline$\left(T 0 \_i m \_k s\right)$ & $(0.071)$ & $(0.084)$ & $(0.533)$ & $(0.996)$ & $(0.533)$ & $(0.995)$ \\
\hline Log of exporter's GDP (EU) & $0.769 * * *$ & $0.777 * * *$ & $0.455^{* * *}$ & $0.455 * * *$ & $0.636^{* * *}$ & $0.636^{* * *}$ \\
\hline$\left(l n \_e x p \_g d p\right)$ & $(0.171)$ & $(0.155)$ & $(0.090)$ & $(0.098)$ & $(0.101)$ & $(0.095)$ \\
\hline $\begin{array}{l}\text { Log of importer's GDP } \\
\text { (Kosovo) }\end{array}$ & 3.025 & 3.172 & 2.919 & $2.919 * * *$ & 3.483 & $3.483^{* *}$ \\
\hline$($ ln_imp_gdp) & $(2.104)$ & $(3.317)$ & $(2.066)$ & $(0.776)$ & $(3.305)$ & $(1.621)$ \\
\hline $\begin{array}{l}\text { Log of distance } \\
(\text { ln_dis_km) }\end{array}$ & $\begin{array}{r}-1.452 * * * \\
(0.291)\end{array}$ & $\begin{array}{r}-0.994 * * * \\
(0.241)\end{array}$ & $\begin{array}{r}-1.470 * * * \\
(0.123)\end{array}$ & $\begin{array}{r}-1.470 * * * \\
(0.116)\end{array}$ & $\begin{array}{r}-1.406 * * * \\
(0.128)\end{array}$ & $\begin{array}{r}-1.406 * * * \\
(0.118)\end{array}$ \\
\hline $\begin{array}{l}\text { Common currency dummy } \\
(\mathrm{comc})\end{array}$ & $\begin{array}{r}-0.523 * * \\
(0.234)\end{array}$ & $\begin{array}{r}-0.574 * * \\
(0.223)\end{array}$ & $\begin{array}{r}-0.334 * * \\
(0.146)\end{array}$ & $\begin{array}{r}-0.334 * * \\
(0.162)\end{array}$ & $\begin{array}{r}-0.513 * * * \\
(0.162)\end{array}$ & $\begin{array}{r}-0.513 * * * \\
(0.179)\end{array}$ \\
\hline $\begin{array}{l}\text { Diaspora dummy } \\
(\text { rem_d })\end{array}$ & $\begin{array}{r}0.119 \\
(0.268)\end{array}$ & & $\begin{array}{r}0.292 * \\
(0.151)\end{array}$ & $\begin{array}{r}0.292 \\
(0.185)\end{array}$ & & \\
\hline $\begin{array}{l}\text { Log Diaspora remittances } \\
(\text { ln_rem })\end{array}$ & & $\begin{array}{r}0.056 \\
(0.183)\end{array}$ & & & $\begin{array}{r}0.075 \\
(0.145)\end{array}$ & $\begin{array}{r}0.075 \\
(0.161)\end{array}$ \\
\hline Constant & $\begin{array}{c}-14.421 \\
(12.410)\end{array}$ & $\begin{array}{r}-18.833 \\
(19.311)\end{array}$ & $\begin{array}{r}-15.426 \\
(11.962)\end{array}$ & $\begin{array}{r}-15.426 * * * \\
(4.513)\end{array}$ & $\begin{array}{r}-20.527 \\
(19.141)\end{array}$ & $\begin{array}{r}-20.527 * * \\
(9.316)\end{array}$ \\
\hline Year dummies & YES & YES & YES & YES & YES & YES \\
\hline $\begin{array}{l}\text { Group means of time- } \\
\text { varying continuous } \\
\text { exogenous variables }\end{array}$ & YES & YES & YES & YES & YES & YES \\
\hline Number of observations & 224 & 202 & 21,722 & 21,722 & 19,588 & 19,588 \\
\hline
\end{tabular}

Levels of significance are indicated in the conventional manner: $* * * \mathrm{p}<0.01 ; * * \mathrm{p}<0.05 ; * \mathrm{p}<0.1$. Standard errors are reported in parentheses.

(i) Models estimated at aggregate and sectoral level, respectively, control for country-pair and country-pair by sector time invariant unobserved effects.

(ii) The Group means of importer's GDP and remittances; Kosovo's GDP is invariant across countries (aggregate data) and country-pair-sectors (sectoral

data), hence the group mean of this variable is cannot be additionally controlled for. (iii) Bootstrapped standard errors with 250 replications. 
In the sectoral data with remittances, the average effect of initial exports on subsequent exports is reflected in the estimated coefficient of 11.497. Other factors held constant, a difference of $€ 100,000$ in the initial level of exports is associated with an average increase in current bilateral exports of 11.50 per cent at the sectoral level. ${ }^{15}$ Similarly, the coefficient on the lagged dependent variable, 0.813 , suggests that an increase in sectoral trade in the previous year of $€ 100,000$ is on average associated with an increase in current bilateral exports of 0.81 per cent. ${ }^{16}$ Specifying with the remittances variable reduces the time series depth for the 11 countries with remittances data to five periods, while estimating with the Diaspora dummy increases the time series depth available for estimation to eight periods. With respect to the coefficient on the lagged dependent variable in the specification with the Diaspora dummy, the estimate is almost identical (0.799) (Table 2, Column 3). For sectoral imports (Table 3), a $€ 1 \mathrm{~m}$ difference in initial imports is associated with a difference in current flows of 65.25 per cent, and a $€ 1 \mathrm{~m}$ difference in first lagged imports is associated with a difference in current flows of 2.32 percent. ${ }^{17}$ These results suggest that the current pattern of Kosovo's trade is not only influenced by the recent past but also by patterns already established by 2005 .

\subsubsection{Cluster-robust estimation of the lagged trade effect}

The coefficient estimates in our export equations generally display some loss of precision when the default standard errors (SEs) are compared to the cluster-robust SEs, which have to be obtained by bootstrapping. ${ }^{18}$ This is to be expected (Cameron and Trivedi, 2010, p.85). However, those effects estimated with acceptable levels of precision according to the default SEs mainly maintain statistical significance at conventional levels according to the cluster-robust SEs. The initial export condition remains significant in one but obtains only borderline significance in the other export model (with p-values of 0.053 and 0.125 respectively) while remaining strongly significant in both import models. Yet in both export models as well as in both import models the bootstrapped cluster-robust SEs on the respective coefficients on the lagged dependent variables are

\footnotetext{
${ }^{15}$ Calculated as $11.497 \times 0.01 \times 100$, where the second term is 0.01 of the unit of measurement $(€ 10 \mathrm{~m})$. $€ 100,000$ is taken as a marginal change given the small scale of Kosovan exports (see Table 1).

${ }^{16}$ Because these coefficients are to be interpreted as semi-elasticities, and given that Kosovan exports have grown over time, the current proportional effect decreases over time.

$17 € 1 \mathrm{~m}$ is taken as a marginal change given the scale of Kosovan imports, which are roughly an order of magnitude larger than Kosovan exports (see Table 1).

${ }^{18}$ We use the Stata vce(bootstrap) option, 'which performs a cluster bootstrap' (Cameron and Trivedi, 2010, p.637).
} 
hugely different from the default standard errors (respectively 2.373 compared to 0.100 and 2.035 compared to 0.095 in the sectoral export models; and 0.257 compared to 0.069 and 0.264 compared to 0.059 in the sectoral import models). In both sectoral export models, this difference between the bootstrapped and default SEs is an outlier: the respective factors by which they differ -24 and 21 - contrasts with respective differences for the other reported SEs by mean factors of 0.93 (ranging between 0.33 and 3.40) and 0.98 (ranging between 0.55 and 2.97). In the sectoral import models, the cluster-robust SEs are greater than the default SEs by a factor of 4.48 in the model with the Diaspora Dummy; and by a factor of 3.74 in the model with remittances.

We have no explanation for the extreme differences between the default and the bootstrapped cluster-robust SEs on the lagged dependent variable. However, we did compare our findings in this respect to the only other published example - to our knowledge - of a dynamic Poisson model with bootstrapped cluster-robust SEs. This appears in Cameron and Trivedi (2013). We replicated their model reported in Table 9.6, Columns 1 and 2, first with bootstrapped cluster-robust SEs (as reported) and then with default OIM SEs (not reported). Comparison revealed much the same contrast evident in our findings; namely, whereas the default and bootstrapped SEs on the coefficient on the lagged dependent variable differed by a factor of 4.46 , the SEs on the other variables differed by a mean factor of 1.63 (ranging between 1.00 and 2.66). Whether or not this similar contrast is a coincidence or indicative of a systematic issue in the bootstrapping of the SEs on the coefficients on lagged dependent variables in dynamic Poisson models will be established by whether or not future studies reveal the same contrast. If so, then this may motivate formal investigation. Here, we offer this finding as information to fellow researchers. With respect to the present study, we tentatively conclude that bootstrapped SEs on the lagged dependent variable in Poisson models may be overinflated and thus does not constitute sufficiently strong evidence for rejecting dynamic specification of our gravity model.

\subsection{Income Elasticities of Trade}

The estimated income elasticities and their effects on Kosovo exports make strong suggestions about the character of Kosovo's exports and how this contrasts with the character of exports from more established market economies (Table 2). The coefficient on the Log of importers' GDP is small and statistically insignificant across all models, suggesting that the immediate impact of an increase in EU income generates little or no increase in Kosovo's exports. Equally noteworthy is the statistically insignificant coefficient on the income elasticity of supply (i.e. the coefficient on Log of exporter's GDP). This may suggest that 
economic development in Kosovo is not yet giving rise to supply capacity yielding increasing exports. This interpretation is tentative, because the lack of statistical significance of this estimate may also reflect the lack of variation of Kosovo's GDP, which varies only in the time-series dimension.

On the import side, we find large income effects on imports (Log of importer's GDP), although only the cluster-robust estimates display statistical significance at conventional levels. These estimated income elasticities - all around three - suggest a great hunger for imports in Kosovo, with increases in demand greatly exceeding increases in income. In contrast, the EU exporters' GDP ( $\log$ of exporter's GDP) produces statistically significant but small estimated elasticities, 0.636 in our preferred model. Variations in the national income of EU countries do not much affect their exports to Kosovo.

Two of these income elasticities are revealing with respect to Kosovo's trade and development. Uniformly high income elasticities of import demand (Table 3, Log of importer's GDP), suggest that economic development in Kosovo has so far induced considerable dynamism in importing. In contrast, there is no case for judging the income elasticities of export supply to be other than zero (Table 2, Log of exporter's GDP estimates range from 0.742 to 5.186 with p-values ranging from 0.15 to 0.94 ), suggesting a lack of dynamism in exporting. This contrast is not unexpected, bearing in mind the stage of development in which Kosovo currently finds itself. Kosovo is still heavily dependent on imports. Although there are concerns regarding the high and persisting negative trade balance, and how the latter will affect the sustainability and the long-run growth prospects of Kosovo, one should be aware that importing, at least in the short run to medium run, is important to Kosovo's economic growth, both in terms of increased consumption and as a channel of technology and knowledge transfer. A recent micro level investigation on the export behaviour of firms in transition countries (which covers Kosovo as well), identifies a positive association between import intensity and both the propensity and intensity of exporting (see Gashi et al., 2014). On the export side, lack of dynamism is consistent with broader supply-side weaknesses that continue to constrain economic development in Kosovo.

\subsection{Distance and Trade Costs}

Distance has a strong negative impact as typically estimated by gravity models of trade. The estimated coefficients are almost uniformly significant at the one per cent level, and their size falls towards or somewhat beyond the upper end of the typical range reported in gravity studies (De Benedictis and Taglioni, 2011, p. 75; in addition, all but one of our 
estimates lie within the typical range reported in the meta-regression of distance effects reported by Disdier and Head, 2008). For illustration, the estimate for aggregate export data reported in Table 2, Column 2 indicates that a one per cent increase in the distance between capital cities, ceteris paribus, reduces the value of exports by 1.023 per cent. The corresponding elasticity estimated for sector exports is -1.039 (Columns 5 and 6).

These negative distance effects are detecting costs in export and import transactions between Kosovo and the EU member states that are likely to vary with distance. Although there have been significant improvements in the transport infrastructure in Kosovo, much more is needed to advance the road and rail infrastructure and to connect to the main regional transport corridors. In this context, Kosovo's lack of access to the sea raises the level of trade costs on both sides. Moreover, unpredictable border delays are common, caused by corrupt or rent-seeking practices, burdensome regulations, and other related inefficiencies. En route delays, and even more importantly a low degree of reliability and predictability of services (that is, unreliable service delivery) increase total logistics costs. Finally, low value-to-weight goods affect the costs of exporting for Kosovo's producers/exporters.

\subsection{Common Currency}

Common currency effects are uniformly statistically insignificant for all models estimated on export data (Table 2). However, for imports, trading in a common currency is negatively associated with the flow of imports to Kosovo (Table 3). Among the four countries with which Kosovo has never shared a common currency during the sample period is Croatia; and among the seven that adopted the euro part way through is Slovenia. Trade with these countries was once internal trade within the former Yugoslavia. Reflecting the influence of history, trade with these countries - particularly imports - is greater than would otherwise be anticipated. Generally, the expectation is that trading in a common currency would have a positive effect on trade flows; and, conversely, that uncertainty induced by trading in different currencies would have a negative effect. Yet the particular history of Kosovo as part of the former Yugoslavia is such that it trades intensively with two countries with which it does not share the euro. In turn, we hypothesise that this imparts a downward bias to the estimated effect of trading in a common currency, which may account for the negative common currency effect on imports.

We tested this hypothesis by estimating our import models after filtering out the observations for Croatia and Slovenia. In all cases, the estimated common currency effect 
was changed from significant to insignificant. ${ }^{19}$ In comparison, the estimated effects of the other variables of interest were broadly similar. ${ }^{20}$ Together with the export effects reported above, our estimated common currency effects are now uniformly statistically insignificant, which is consistent with recent meta-regression evidence (Havranek, 2010), even though many individual studies report a positive impact of a common currency on trade flows (Rose 2000; and Frankel and Rose, 2002).

\subsection{Diaspora Community}

Finally, the large, positive and highly significant influence of diaspora communities on Kosovo's aggregate and sector exports (Diaspora dummy, Table 2, Columns 1, 3 and 4) suggests the importance of personal and community networks. The size of the coefficients is high, indicating the importance of the diaspora community in exporting to the EU countries where the Kosovo diaspora is large relative to the EU countries where the Kosovo diaspora is small in numbers or non-existent. Across these two regressions the estimated impact of a discrete change from 0 to 1 in the dummy variable comparing countries with little or no diaspora community (dummy $=0$ ) to countries with a large diaspora community (dummy=1) is around two. While we do not insist on a precise quantitative interpretation of these estimates, the evidence suggests that the diaspora effect on Kosovo's exports is large. This judgement is confirmed by our second approach to estimating the trade effects of a diaspora community, which is to measure the importance of the diaspora community by the size of remittances from each country in each year. Log Diaspora remittances is a continuous variable, so that the estimated coefficients are to be interpreted as constant elasticities (Columns 2, 5 and 6). These suggest that an increase in diaspora remittances of one per cent is associated with an increase in bilateral exports of between 1.1 per cent and 1.5 per cent.

In contrast, the import effect is not robustly estimated by either the Diaspora dummy or the continuous variable Log Diaspora remittances: five from six estimates are not statistically significant at conventional levels. Moreover, the theoretical reasons for hypothesising an import effect are less strong than in the case of exports. Hence, we conclude that there is no systematically significant diaspora effect on Kosovo's bilateral

\footnotetext{
${ }^{19}$ For the two aggregate models, $\mathrm{p}=0.617$ and $\mathrm{p}=0.901$ respectively (corresponding to models 1 and 2 reported in Table 3); for the two sectoral models with default standard errors, $\mathrm{p}=0.414$ and $\mathrm{p}=0.571$ respectively (models 3 and 5 reported in Table 3); and for the two sectoral models with bootstrapped cluster-robust standard errors $\mathrm{p}=0.325$ and $\mathrm{p}=0.478$ (models 4 and 6 reported in Table 3 ). Moreover, in five from six of these models the estimated effect was positive.

20 These additional estimates are available on request.
} 
imports. Broadly, our findings on the differential trade effects of exports and imports are in line with 'a sizable literature of gravity-based estimates of the effect of migration on trade' (Egger et al., 2012, p.221):

... with very few exceptions, these papers consistently find significant positive effects of immigration on trade ... Furthermore, of the papers that report results for both imports and exports, it was about twice as common to find the estimated effect of immigration on imports greater than that on exports.

(In the context of our study, the import effects of migration are to be interpreted as their inverse - i.e. the export effects of a diaspora community.)

Whichever approach we use to calculate the diaspora effect on exports, it is sufficiently large to be worthy of attention from policy makers. ${ }^{21}$ Because the costs of trading goods between Kosovo and the EU are so high (see the discussion on distance and trade costs), it is likely that Kosovo's businesses will promote exports through their business compatriots in the diaspora to obtain the necessary information regarding the market, legal and regulatory burden, contract enforcement, and even utilize diaspora distribution channels (retail and wholesale). In addition, diaspora communities would be able to close cultural and language gaps, which are serious impediments to international trade transactions.

\subsection{Further Investigation: Recognition Effects}

To investigate the possibility that recognition of Kosovo as a sovereign nation might have intensified trade flows, we re-estimated the models with default standard errors to include a dummy variable (Recognition_dummy) which takes the value one in years when Kosovo's independence was recognised by the partner country (i.e. the year of recognition and subsequent years), and zero otherwise. ${ }^{22}$ All countries in the sample except Cyprus, Greece, Romania, Slovakia and Spain recognised Kosovo in 2008. This variable proved statistically insignificant in all model specifications while inducing no noteworthy changes to the estimates reported in Tables 2 and 3 above.

\footnotetext{
${ }^{21}$ Indeed, Kosovo has a Ministry of Diaspora.

${ }^{22}$ We thank an anonymous referee for this suggestion. We did not estimate these augmented models with bootstrapped cluster-robust standard errors, as these models can take up to several days to iterate to a solution.
} 


\section{CONCLUSIONS}

To inform policy making following trade liberalisation within the framework of Kosovo's SAA with the EU, we specify a gravity model to investigate Kosovo's trade in goods with 28 EU countries, over the period 2005-2013. We reconcile competing methodological requirements to estimate a dynamic Poisson specification.

All of our trade models estimated with default standard errors show large, positive and highly statistically significant coefficients both on lagged trade and on initial trade conditions. However, the evidence from the sector models estimated with bootstrapped cluster-robust standard errors is mixed. In the absence of established practice with respect to the estimation of cluster-robust standard errors in dynamic Poisson models, especially on the lagged dependent variable, we conclude that our findings are consistent with previous arguments in the literature for dynamic specification of the gravity model. Economically, these results reveal both a high level of persistence in Kosovo's trade from year to year and the major influence of trade patterns established in the more distant past.

Low and uniformly insignificant estimated income elasticities of demand for Kosovo's exports suggest that Kosovo produces goods for which EU demand grows little or not at all with rising income. Conversely, we find some indications of very high income elasticity of demand for imports in Kosovo. Together, these demand elasticities are consistent with uniformly insignificant export supply elasticities for Kosovo, meaning that increases in national income are not yet generating corresponding export capacity. These results suggest that Kosovo's trade is not yet responding fully to traditional trade determinants. In other words, the character of Kosovo's trade with the EU contrasts with the character of international trade between more established market economies. Particularly when it comes to exporting, the approach to economic development in Kosovo is not yet of the kind that stimulates exporting firms and industries.

The combined influence of persistent trade patterns and an unfavourable combination of demand and supply elasticities suggests that trade liberalisation in isolation is not sufficient to promote exports but may need to be incorporated within a wider policy and institutional framework. Our general conclusion is consistent with the conclusions of a recent joint report of the OECD/WTO/World Bank (2014, pp. 12-13):

Actual experience and studies place a greater emphasis on domestic measures taken to enhance countries' production capacities ... Trade liberalisation may thus be important, but it is only one ingredient among many others. A trade agreement by itself cannot put a given country on the right path, regardless of its ambitions 
or content; this can be achieved only by the country itself, acting on an understanding of what must be done and the political will to do it.

In addition, our findings suggest trade costs as a particular focus for policy: distance, proxying trade costs, has a big negative influence on Kosovo's exports to the EU countries; while the diaspora effect suggests that Kosovo's exports are responding strongly to other, less conventional factors. Diaspora communities promote Kosovo's exports to EU markets, most likely because they offset trade costs. This effect highlights the importance of personal and community networks, which help to reduce high transaction costs between Kosovo and the EU countries.

Methodologically, this paper contributes by estimating a gravity model that reconciles competing claims: consistency with current theoretical models; the advantages of Poisson estimation; and the case for a dynamic specification. We suggest that the dynamic Poisson model advanced in this study is particularly suitable for investigating trade flows in situations where the main influences on trade, including trade policy, may reasonably be treated as exogenous.

In the course of this investigation, we uncover an issue arising from the bootstrapping of cluster-robust standard errors for the effect of the lagged dependent variable in dynamic Poisson models. In this context, the only other published model reporting bootstrapped cluster-robust standard errors indicates the same effect. Namely, in comparison with the standard errors on the other coefficients in the estimated model, the standard error on the effect of the lagged dependent variable is disproportionately inflated. However, within the confines of this study, we are unable to determine the extent to which this may be a systematic effect requiring separate investigation.

The main inherent limitations of this study arise from data constraints at the time of the study. For the period and quality of data required, we were restricted to analyzing Kosovo's bilateral trade in goods with the countries of the EU. As new data becomes available, we anticipate extending this analysis to incorporate services and, eventually, the entire matrix of Kosovo's trade.

\section{REFERENCES}

Anderson, James E., 1979. A theoretical foundation for the gravity model. American Economic Review 69(1), 106-116.

Anderson, James E., 2010. The gravity model. Working Paper No. 16576. NBER, Massachusetts. 
Anderson, James E., van Wincoop, Eric, 2003. Gravity with gravitas: a solution to the border puzzle. American Economic Review 93(1), 170-192.

Anderson, James E., van Wincoop, Eric, 2004. Trade costs. Journal of Economic Literature 42(3), 691-751.

Baldwin, Richard, Taglioni, Daria, 2007. Trade effects of the Euro: a comparison of estimators. Journal of Economic Integration 22(4), 780-818.

Bernard, Andrew B., Jensen, Bradford, J., 2004. Why some firms export? The Review of Economics and Statistics 86(2), 561-569.

Bernard, Andrew. B., Wagner, Joachim, 1998. Export entry and exit by German firms. Working Paper No. 6538. NBER, Massachusetts.

Cameron, Colin, Trivedi, Pravin, 2010. $2^{\text {nd }}$ Ed. Microeconometrics Using Stata. The Stata Press: College Station, Texas.

Cameron, Colin, Trivedi, Pravin, 2013; $2^{\text {nd }}$ Ed. Regression Analysis of Count Data, Econometric Society Monograph No.53, Cambridge: Cambridge University Press.

Carrère, Céline, 2014. Can Mirror Data Help to Capture Informal International Trade? Policy Issues in International Trade and Commodities, Research Study Series No. 65. Geneva: UNCTAD.

Clercq, Dirk De, Sapienza, Harry J., Crijns, Hans, 2005. The internationalisation of small and medium-sized firms. Small Business Economics 24, 409-419.

De Benedictis, Luca, Taglioni, Daria, 2011. The gravity model in international trade. In: De Benedictis, Luca, Salvatici, Luca (Eds.), The Trade Impact of European Union Preferential Policies: An Analysis through Gravity Models, Springer, Berlin.

Disdier, Anne-Célia, Head, Keith, 2008. The Puzzling Persistence of the Distance Effect on Bilateral Trade. Review of Economics and Statistics, 90(1): 37-48.

Egger, Peter, Ehrlich, von Maximilian, Nelson, Douglas ,2012. Migration and Trade. The World Economy, doi: 10.1111/j.1467-9701.2011.01429.x

Eichengreen, Barry, Irwin, Douglas A., 1998. The role of history in bilateral trade flows. In: Frankel, Jeffrey A. (Ed.), The Regionalization of the World Economy, University of Chicago Press, Chicago, pp.33-62. Available at http://www.nber.org/chapters/c7819.pdf

Frankel, Jeffrey, Rose, Andrew, 2002. An estimate of the effect of common currencies on trade and income. The Quarterly Journal of Economics 117, 437-466.

Gashi, Petrit, Hashi, Iraj, Pugh, Geoffrey, 2014. Export behaviour of SMEs in transition countries. Small Business Economics 42, 407-435. 
Gashi, Petrit, Pugh, Geoffrey, 2015. Kosovo's trade with the EU: looking beyond the stabilisation and association agreement. Kosovo Foundation for Open Society (KFOS), Pristina, Kosovo. Available at (accessed 15-04-2015) http://kfos.org/marredheniet-tregtare-mes-kosoves-dhe-be-se-shikim-pertejmarreveshjes-per-stabilizim-dhe-asocim/

Gould, David M., 1994. Immigration links to the home country: empirical implications for US bilateral trade flows. Review of Economic and Statistics 76(2), 302-316.

Greene, William, 2008. Econometric Analysis, $6^{\text {th }}$ ed., Prentice Hall, New Jersey.

Guo, Dong, 2009. Mirror Statistics of International Trade in Manufacturing Goods: The Case of China. Research and Statistics Branch, Working Paper 19/2009. Vienna: UNIDO.

Havranek, Tomas, 2010. Rose effect and the Euro: is the magic gone? Review of World Economics 146(2), 241-261.

Head, Keith, Mayer, Thierry, 2013. What separates us? Sources of resistance to globalization. Canadian Journal of Economics 46(4), 1196-1231.

Melitz, Marc J., 2003. The impact of trade on intra-industry reallocations and aggregate industry productivity. Econometrica 71(6), 1695-1725.

Newberry, David, Stiglitz, Joseph, 1984. Pareto Inferior Trade, Review of Economic Studies, LI, 1-12.

Organisation for Economic Co-operation (OECD) / World Trade Organisation (WTO) / World Bank Group, 2014. Global value chains: challenges, opportunities, and implications for policy. Report prepared for submission to the G20 Trade Ministers Meeting, Sydney, Australia.

Parsons, Christopher R., 2012. Do migrants really foster trade? The trade-migration nexus, a panel approach 1960-2000. Policy Research Working Paper No. 6034. The World Bank.

Redding, Stephen, Venables, Anthony, 2004. Geography and export performance: external market access and internal supply capacity. In: Baldwin, Robert E., Winters, Alan L. (Eds.), Challenges to Globalization: Analyzing the Economics, University of Chicago Press, pp.95-130. Available at http://www.nber.org/books/bald04-1

Roberts, Mark J., Tybout, James R., 1997. The decision to export to Columbia: an empirical model of entry with sunk costs. American Economic Review 87(4), $545-564$.

Rose, Andrew K., 2000. One money one market: estimating the effect of common currencies on trade. Economic Policy 15, 7-46. 
Santos Silva, Joao, Tenreyro, Silvana, 2006. The log of gravity. The Review of Economics and Statistics 88(4), 641-658.

Santos Silva, Joao, Tenreyro, Silvana, 2011. poisson: some convergence issues. The Stata Journal 11(2), 207-212.

Shepherd, Ben, 2013. The Gravity Model of International Trade: A User Guide. United Nations ESCAP. Available at (accessed 05-10-2013) http://www.unescap.org/tid/publication/tipub2645.pdf

Simola, Heli, 2012. Russian import statistics in the mirror of world exports. BOFIT Online 2012 No. 2. Helsinki: Bank of Finland.

Wooldridge, Jeffrey M., 2005. Simple Solutions to the initial conditions problem in dynamic, nonlinear panel data models with unobserved heterogeneity. Journal of Applied Econometrics 20, 39-54.

World Trade Organisation (WTO), 2012. A Practical Guide to Trade Policy Analysis. World Trade Organization, Geneva. Available at (accessed 16-04-2015) https://www.wto.org/english/res_e/publications_e/practical_guide12_e.htm 